\title{
The Use of Power Point Presentations to Motivate First Year Secondary School students to learn English THE CASE OF OUED TAGA SECONDARY SCHOOL, BATNA
}

\author{
Received: 23/01/2018; Accepted: 03/02/2019
}

\section{Abstract}

This study attempts to show how to motivate First year secondary school pupils to learn English through the use of one of the ICT's (Information and Communication Technologies), Power Point Presentations, in the process of teaching and learning English in secondary schools. A pre-test and a post-test are used with a group of 35 students selected randomly. They are taught using power point presentations of some selected items in their units using projectors for a period of 20 weeks. Second, we have utilized two questionnaires, one for EFL teacher in secondary schools and the other for students, in addition to a classroom observation. The obtained results revealed the effectiveness of teaching via PPPs, although some learners prefer the traditional way of learning.

Keywords: ICT's (Information and Communication Technologies) 2; Motivation to learn Power Point Presentations, 3;Teaching English in secondary schools

\section{Samia Maallem *}

Faculty of Letters and Languages

Department of Foreign Languages

University of Mentouri

Constantine I

(Algeria)

\section{Résumé}

Cette étude tente de motiver les élèves de première année à apprendre l'anglais grâce à l'utilisation de Power Point Présentations, dans les écoles secondaires. Un pré-test et un post-test sont utilisés avec un groupe de 35 étudiants .Ils apprennent en utilisant des présentations PowerPoint de certains éléments sélectionnés dans leurs unités en utilisant des projecteurs pendant 20 semaines. Deuxièmement, nous avons utilisé deux questionnaires, un pour les enseignants et un pour les élèves, en plus d'une observation en classe. Les résultats obtenus ont révélé l'efficacité de l'enseignement via Power Point Presentations, mais certains apprenants préfèrent encore la méthode traditionnelle d'apprentissage.

Mots clés: TIC 2 ;Motivation pour apprendre les présentations PowerPoint, 3 :Enseigner l'anglais dans les écoles secondaires

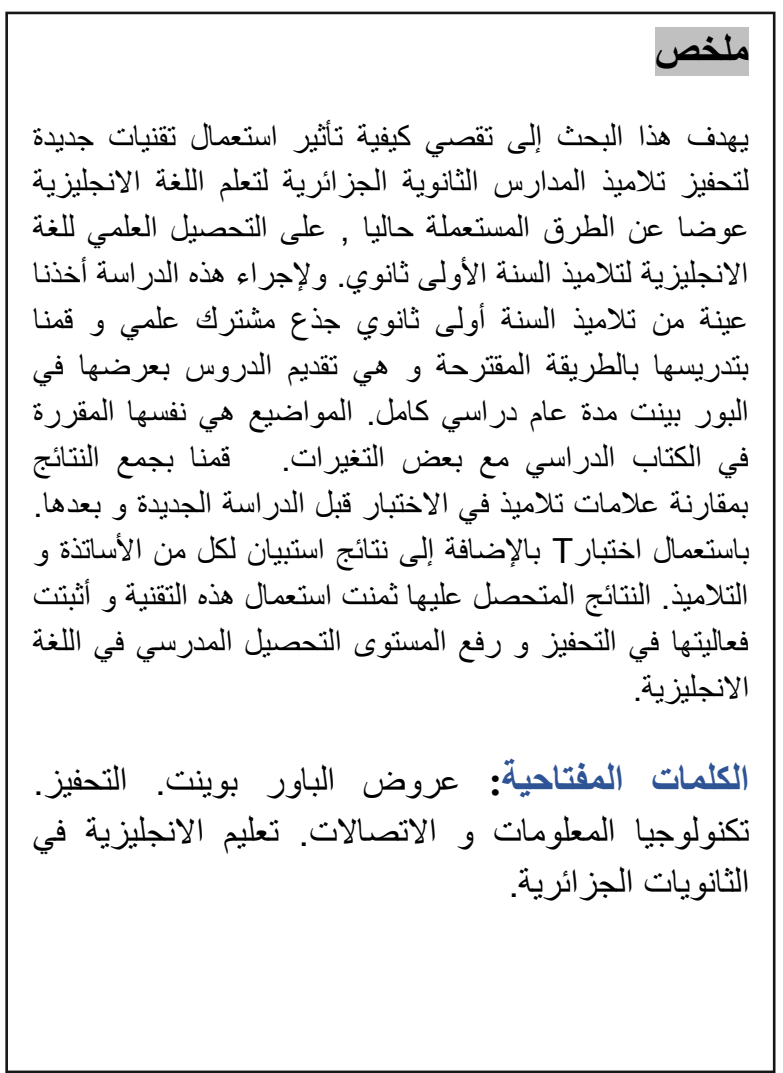

* Corresponding author, e-mail: samia.maallem@yahoo.com 


\section{Introduction}

With the spread and development of English around the world, English is used as a foreign language in a country like Algeria (together with French as a first foreign language). As the number of English learners is increasing, different teaching methods have been implemented to test the effectiveness of the teaching process. The new era assigns new challenges and duties on the modern teacher. The tradition of English teaching has been drastically changed with the remarkable entry of technology. Technology provides so many options as making teaching interesting and also making teaching more productive in terms of improvements. It is utilized to satisfy both visual and auditory senses of the pupils. With the spread and development of English around the world, English has been learned and used by more and more speakers.

The influence of visual technology in teaching has proved to be undeniable in recent years. Hence, this study aimed to determine the effect of teaching first year secondary school pupils using power point presentations instead of relying only on textbooks and whiteboards. This article is devoted to check the effective of teaching secondary school pupils with power point presentations as a motivational method or technique to raise interest and involvement inside the classroom and during English sessions, in addition to the improvement of their scores and achievements in English.

\section{Literature Review}

\section{Power point presentations}

In recent years, the use of PowerPoint in the classrooms has increased significantly, and has attracted many researchers to test its effect in education. Some of the studies have tried to measure the effect of PowerPoint on the students' attitudes and behaviors, while others have focused on its effect on the students' academic performance. Microsoft Power-Point is a presentation program developed by Microsoft. It is a part of the Microsoft Office system which is widely used by business people, educators, students, and trainers. As a part of the Microsoft Office suite, Power-Point has become the world's most widely used presentation program.

Supporters of Power Point Presentations like Antherson (2003), contended that cognitive achievement depends on several factors among which are the instructional methods, learning environment and the learner. The brain does not pay attention to boring things. What makes PowerPoint presentations so effective is that they add complementary, multisensory events designed to spark an emotional response among audience members. This helps maintain audience attention and improves cognitive achievement. The most effective presentations are the ones that are informative, educational, and entertaining. For instance, Gier and Kreiner (2009) who studied the 
effectiveness of PowerPoint in a psychology class concluded that when students were actively engaged in the class using PowerPoint presentation, information retention increased.

Cashman and Shelly (2000) find that learners learn most effectively when their five senses are involved. The PowerPoint presentations appeal to learners' diverse learning styles, such as visual, auditory, kinesthetic, and creative by employing multimedia methods, such as sounds, images, color, action, design, and so on.

\section{Retention}

Instead of memorizing facts for a test, teachers want their pupils to retain the information longer than a week. Teachers find it difficult to teach more and more curriculum (Wolfe, 2001). Just covering the entire curriculum does not build strong connections in pupil's memory. As pupils collect new information that is unfamiliar and relate that material to information they already know, then they will be able to retain this new information more easily. Pupils need to watch what they learn in order to remember.

Nowadays, the stereotyped traditional teaching methods and environment are unpopular, while multimedia technology featuring audio, visual animation effects naturally and humanely. Multimedia technology offers a sense of reality and functions very well, which greatly cultivates pupils' interest and motivation in study and their involvement in class activities. This generation of learners is grown up in new area where technology dominates their life. They are motivated and stimulated by new technologies. For this reason they may retain more information if technology is used in their classrooms. Computers, projectors, videos, songs, audiovisuals and other technological tools are more effective strategies than the traditional methods (Miller, 2009). They spur interest in learners and are likely to motivate them to perform at a higher level.

\section{Motivation and Technology in Education}

The literature review points out that there are several contributing factors to the practicalities of a true innovation. The first contributing factor is motivation. According to Harmer (2001) "motivation is some kind of internal drive which pushes someone to do things in order to achieve something." (p. 51). Motivation includes all of the wants, wishes, efforts, abilities, potentials, engagements, and the persistence to attain and reach desired goals in a form of positive achievement.

. It also suggests that educational technology can help to motivate learners of English as a Second Language develop language skills and as stated by Eggen and Kauchak (2004: 
414), "in terms of research as having positive effects of technology on motivation in at least four areas: self-esteem and self-efficacy, attendance, attitudes, and involvement". However, not all lecturers in schools are putting this knowledge into practice as they are still not utilizing the technology tools provided for them to use in their teaching methods. Pupils are becoming more advanced in the use of technology, and if teachers do not follow this trend, they will be out-of-date. In order to keep-up with the trends in education, teachers need to incorporate technology into their teaching. However, many teachers are still unaware of the benefits or purposely ignoring the fact that pupils enjoy using technology to learn.

When we talk about technology in education we should first define the word ICT (Information and Communication Technology). According to Kennewell (2004), ICT covers all aspects of computers, networks (including the Internet) and certain other devices with information storage and processing capacity such as calculators, mobile phones and automatic control devices and applications.

Fisher (2003) suggests using Power Point for ESL teaching. Power Point is a type of presentation software that allows users to show coloured text and images with simple animation and sound. He explains that "Power Point has been in existence for many years, it has just begun to spread to schools and ESL classrooms... [and]...the reason for this delay is that technology requires hardware, which is relatively expensive." However, this is not a problem for presentation software like Microsoft Power Point. It is easily available and usually comes bundled with most of the office computers as part of the Microsoft Office package. Though, many are still unaware of how useful it can be as an aid in teaching. This study involves the use of Microsoft Power Point to teach and learn the English language. Effects on pupils' motivation, attitude and anxiety in learning through the use of Microsoft Power Point are investigated. This provides an insight into the effectiveness of the technique with goals of improving instruction, teaching methods and other pedagogical practices employed by teachers.

Teaching English or any other foreign language in the secondary schools with large classes (35-50 pupils) can be said to be a nightmare for both teachers and pupils. As I started teaching, I found the use of Power Point presentations a useful audio-visual aid in my classes, especially at the beginning of each new unit where I need to introduce new notions, ideas and terminologies. At the beginning it seems to be difficult and a challenging task especially that I was not very good at using all the computer softwares. But through practice it becomes easier and enjoyable. I was astonished and amazed with the results; pupils were active and involved and more concentrated during the lesson. This 
first experience was on 2014, where I started to integrate technology to my classrooms and to my lessons. As a result, pupils need to be involved and integrated using new methods and techniques, and we believe that Power Point Presentations are effective.

\section{Problems with Power Point Presentation:}

One of the major shortcomings of using Power Point Presentations is that it relies totally on projectors which can be quite expensive to get. The second point here is that, it may happen that the projector stop suddenly or something goes wrong with it. In this case, we should never depend only on the projector. The solution is always to carry a back-up in a non-presentation form so as to replace the Power Point Presentations in case something happens. Tufte (2003) thinks that the learners feel ignored in the classroom when the instructor is focusing on the presentation and not paying attention to the class, Instead of interacting with learners during the class. However, this should not prevent us from appreciating one of its useful functions. One of these is "the way it can help us crystallize our thoughts and then to arrange them". (Rank \& Warren, 2011).

\section{Methodology}

This research is using the quasi experiment method using, a pre-test post-test. The literature in methodology highlights the importance of multiplying data sources using different types of instruments in order to diversify information sources and analyze the problem from different angles.

\subsection{The Setting}

The setting where teachers perform their work plays an important role in both teaching process and motivating pupils. In our case, our setting is Oued Taga (fréres Yalouz) secondary school (Wilaya of Batna). We deal with both teachers of English and first year scientific stream pupils as the sample population for the academic year $2016 / 2017$

\subsection{Aims of the Study}

This study aims at the following objectives :

To encourage secondary school teachers of English to use PPPs in the future life during their lectures.

To highlight the importance and effectiveness of power point presentations in teaching English

To explain how technologies can be used to motivate and stimulate pupils to learn English. 
To expose teachers and students to the need of implementing new technologies in education

\subsection{Research Questions and Hypotheses}

This study aims at answering the following questions:

What are the effects of teachers' using PowerPoint Presentations in the class on pupils' learning and scores at Oued Taga Secondary School?

Can PowerPoint Presentations enhance motivation in first year secondary school pupils?

Our hypothesis is derived directly from the above questions:

If secondary school teachers of English made use of technologies in their classes especially power point presentations in teaching English, then their pupils would get good results and they would understand their lessons better.

In other words, if first year (Scientific Stream) secondary school pupils were taught English using power point presentations, then they would be motivated and eager to understand more what they study.

\subsection{The Participants}

The experiment was conducted with first year secondary school pupils in Oued Taga in Batna. A class from the scientific stream was chosen for this investigation from the whole population of first year pupils. It contains 35 pupils. This table will explain the pupils' number and gender.

Table1. Information about the pupils' gender

\begin{tabular}{|c|c|c|}
\hline Gender & Males & Females \\
\hline Group & 18 & 17 \\
\hline Total & & \\
\hline
\end{tabular}

\subsection{Research Instruments}

Our study uses the following means:

\subsubsection{The First, Mid and Last Term Examinations}

These are the usual achievement examinations taken by all the pupils, and they are elaborated by all the teachers of the English language in the secondary school. These examinations or tests are used to check the pupils' achievements in the English 
language after each trimester. And the three different scores are used to check the pupils' improvement through the whole school year.

\subsubsection{Lesson Plan}

"All good teachers have some type of plan when they walk into their classrooms."(Jensen, 2001:403) These lesson plans are used as maps that the teacher uses to know "what to teach, in what order, and for how much time [needed to be taught]." (Jensen, 2001:403) Based on these ideas we design a range of lesson plans that are used to investigate the pupils' academic achievement and attitudes toward learning English as a foreign language. The lesson plans used in our study are designed based on the first year secondary school textbook "At the crossroads." We select the teaching activities that fit the learners' needs and the technology we used, and many times we reject some of the textbook activities and replace them by others adapted from different resources.

\subsubsection{Classroom Observation}

Classroom observation has always been considered as a major data collection tool in qualitative research. It is also potentially the most useful and practical means to study classroom phenomena. In this respect, Seliger and Shohamy (2000) posit that:

\section{Observations are most often used to collect data on how learners use language in a variety of settings, to study language learning and teaching processes in the classroom, and to study teacherse and students ${ }^{\text {ee }}$ behaviour}

$$
\text { (Seliger \& Shohamy, }
$$

2000:162)

Thus, the purpose of the class observation is to identify how the procedures are going on in the field itself, as it allows the observer to record information about the lessons' content, the teaching materials involved in such lesson and the different steps constituting that lesson.

Because it seems necessary for the investigator to take account of a number of considerations in planning the observational phase, we needed to consider a variety of factors such as:"The number of observers and observed, the frequency and duration of observations, and how the observational data are collected, tabulated, and analyzed" (Cohen, 1998:31).Hence, in the present research the class is observed for a number of times over the regular school year, for eight 08 weeks: one hour a week. This aims at making learners more familiar and less distracted, because“...If the observer...is present during several lessons, pupils may become accustomed and consequently revert back to their normal classroom behavior" (Cohen, 1998:33) .In essence, such research 
instrument would enable us to establish fixed ideas about the teaching situation being investigated through the direct contact with the class.

The number of informants under investigation is thirty five (35). To collect the necessary data, we had recourse to note taking. By sitting at the end of the class and taking notes about the following criteria: learners' interest and motivation, teacher's methodology and used materials. We have also found it appropriate to use an observation checklist.

\subsubsection{Questionnaires}

Questionnaires are administered to both teachers of English in the secondary school to investigate pupils' motivation toward learning English as a foreign language, and teachers' opinions about using Power Point presentations instead of the traditional way of teaching. Teachers' questionnaire consists of 19 questions varying from personal information to teaching methods and techniques. The pupils' questionnaire is composed of 15 questions that include their opinions about the English session, the English teacher and the way they learn English.

\subsubsection{The Treatment (The Procedure)}

The group is instructed by us (their teacher). The sample is exposed to power point presentations of the topics suggested in their textbook with some modifications. At the beginning of the year, a pretest is given to the pupils and at the end of the year a posttest is given in order to compare the mean scores of the two tests. The group has a total of 60 hours of Power Point Presentations teaching within 20 weeks; i.e. 3 hrs of English learning per week for scientific stream.

\subsection{The Results}

\subsubsection{The results from the tests and exams}

The scores of pupils' pretest, posttest and exams are computed through the Statistical Package for Social Sciences SPSS 24. Our group consists of 35 pupils, but our main study is to observe the pupils low mark and check the progress of those pupils. Thus, we have selected 30 pupils whose marks are between 4 and 12 .

First, the t-test is applied to verify whether or not there is a significant difference between the mean scores of the pupils' scores in the two tests before and after instruction, as showed in table2: 
The Use of Power Point Presentations to Motivate First Year Secondary School students to learn English THE CASE OF OUED TAGA SECONDARY SCHOOL, BATNA

Table 2: T-test results of the pre-test and the post test

\begin{tabular}{|c|c|r|r|r|r|}
\hline \multicolumn{7}{|c|}{ Paired Samples Statistics } \\
\hline \multirow{2}{|c|}{} & \multicolumn{1}{|c|}{ Mean } & \multicolumn{1}{c|}{ N } & Std. Deviation & \multicolumn{1}{c|}{ Std. Error Mean } \\
\hline \multirow{2}{*}{ Pair 1 } & Post-test & 12.63 & 30 & 1.956 & .357 \\
\cline { 2 - 6 } & Pre-test & 8.07 & 30 & 2.935 & .536 \\
\hline
\end{tabular}

The results from the table above, shows that there is a significant difference between the two tests, The mean in the pre-test $=8.07$ and the mean in the post-test $=12.63$. This means that there is indeed an improvement and change in their scores after being taught with power point presentations..

Table3: t-test results of the paired sample

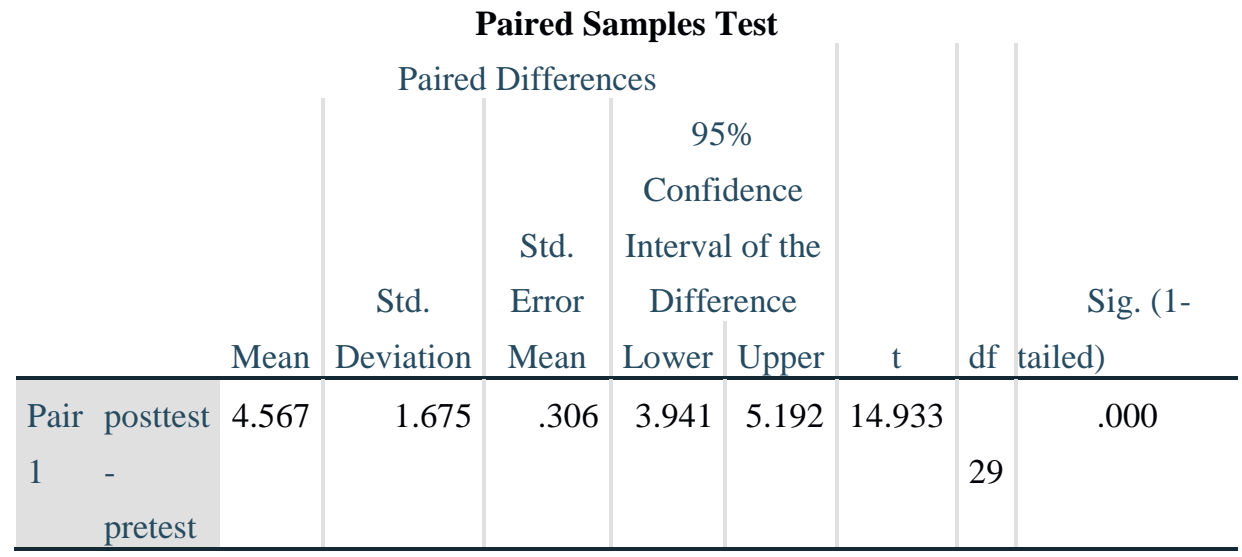

As table 3 presents, the $t=14.93$ for 29 degree of freedom and at 0.02 level of significance. These results reveal that there is indeed a significant difference between pupils' pre-test and post-test results.

The following tables will explain the progress of the pupils' marks in their exams during the academic year 2016/2017 in comparison to their scores in the pre-test and post-test.

Table 4: the difference between the pupils' scores

\begin{tabular}{|l|l|r|r|r|r|}
\hline \multicolumn{2}{|c|}{} & Mean & N & Std. Deviation & Std. Error Mean \\
\hline Pair 1 & Pre -test & 8.07 & 30 & 2.935 & .536 \\
\cline { 2 - 6 } & Exam 1 & 8.90 & 30 & 2.551 & .466 \\
\cline { 2 - 6 } & Exam 2 & 10.40 & 30 & 2.415 & .441 \\
\cline { 2 - 6 } & Exam 3 & 12.10 & 30 & 2.023 & .369 \\
\cline { 2 - 6 } & Post-test & 12.63 & 30 & 1.956 & .357 \\
\hline
\end{tabular}

As the above table shows, there is a little difference between the mean of pre-test and exam1 8.07 and 8.90, while there is a significant difference between the mean of 
exam1 and exam2, 8.90 and 10.40. Also there is a considerable difference between the mean of exam2 and exam 3, 10.40 and 12.10. Finally, there is a slight difference between the mean of exam 3 and the post-test 12.10 and 12.63. From the above results, we can assume that the slight difference the mean of the pre-test and exam1 is due to the time between the two 2 months; pupils are not yet familiar with the new technique of teaching. On the other hand, the results are increasing during the following exams, which prove the effectiveness of the Power Point Presentations that appear in the pupils' marks.

\subsubsection{The Questionnaire Results}

\subsubsection{Teachers' questionnaire}

The questionnaire addresses nine EFL secondary school teachers at Oued Taga secondary school in Batna. The aim behind this questionnaire is to explore the use of technology in our secondary school and its effects on pupils' motivation and learning of English. The questionnaire is divided into four sections, the first one entitled personal information. The first question within this section is about gender, as we can see in the following table the majority of secondary school teachers are females $77.8 \%$, and only $22.2 \%$ are males. This is because teaching the most suitable job for women in Algeria, besides men tend to study or work in scientific fields

Table 5. The Teachers' Gender

\begin{tabular}{|l|l|r|r|}
\hline \multirow{2}{*}{ Gender } & Male & \multicolumn{1}{|c|}{ Number } & Percent \\
\cline { 2 - 4 } & Female & 2 & $22.2 \%$ \\
\cline { 2 - 4 } & Total & 7 & $77.8 \%$ \\
\hline
\end{tabular}

The second section of the teachers' questionnaire entitled teaching experience; its first question is about the teaching experience. In the field of teaching, experience plays an important role. The aim of this question is to find out the duration of teaching (short, average or long). Eight teachers of English in Oued Taga secondary school hold the license degree and only one holds the master degree, but the length of their teaching experience which is ranged from 4 to 20 years is explained in Table 6:

Table 6. Teaching Experience

\begin{tabular}{|l|lcr|}
\hline & \multicolumn{2}{c|}{} & Frequency \\
\hline \multirow{2}{*}{$\begin{array}{l}\text { Teaching } \\
\text { exoerience }\end{array}$} & less than5 years & 4 & $44,4 \%$ \\
\cline { 2 - 4 } & $\mathbf{5 - 1 0 y e a r s}$ & 3 & $33,3 \%$ \\
\cline { 2 - 4 } & $\mathbf{1 0 - 1 5}$ years & 1 & $11,1 \%$ \\
\cline { 2 - 4 } & more than 15 years & 1 & $11,1 \%$ \\
\hline
\end{tabular}


Table 7. Pupils' Motivation

\begin{tabular}{|c|c|c|c|}
\hline & & Frequency & Percent \\
\hline \multirow{2}{*}{$\begin{array}{l}\text { Pupils' } \\
\text { Motivation }\end{array}$} & not very & 5 & $55.6 \%$ \\
\hline & a little & 4 & $44.4 \%$ \\
\hline
\end{tabular}

According to the results shown in table $7,55.5 \%$ of the respondents claim that their pupils are not really motivated. On the other hand, $44.4 \%$ of teachers answer that their pupils are a little motivated. These results confirm our declaration at the very beginning of our study; that is our pupils lack motivation to learn English.

Table 8. The frequency Use of PPPs

\begin{tabular}{|l|l|c|c|}
\hline \multicolumn{2}{|c|}{} & N & Percent \\
\hline \multirow{3}{*}{ The Use of } & never & 2 & $22.2 \%$ \\
\cline { 2 - 4 } & rarely & 4 & $44.4 \%$ \\
\cline { 2 - 4 } & sometimes & 3 & $33.3 \%$ \\
\cline { 2 - 4 } & Total & 9 & $\mathbf{1 0 0 \%}$ \\
\hline
\end{tabular}

The aim behind this query is to divulge how often secondary school pupils make use of Power Point Presentations in their courses. The results, as presented in table 8, demonstrate that $44.4 \%$ of teachers use PPPs rarely, $33.3 \%$ use it sometimes and $22.2 \%$ of them have never used it. Such results reveal that power point presentations' use is not so familiar in secondary schools.

Table 9. Students' Reaction to The Use PPPs

\begin{tabular}{|l|l|r|c|}
\hline \multicolumn{2}{|c|}{} & Frequency & Percent \\
\hline \multirow{3}{*}{$\begin{array}{l}\text { Pupils' Reaction To } \\
\text { PPPs }\end{array}$} & very positive & 4 & $\mathbf{5 0 \%}$ \\
\cline { 2 - 4 } & Somehow positive & 3 & $\mathbf{3 7 . 5 0 \%}$ \\
\cline { 2 - 4 } & Not very positive & 1 & $\mathbf{1 2 . 5 0 \%}$ \\
\cline { 2 - 4 } & Total & $\mathbf{8}$ & $\mathbf{8 8 . 9 \%}$ \\
\hline
\end{tabular}

Another question is asked to the teachers about their pupils' reaction towards learning via Power Point Presentations. 50\% of teachers state that pupils enjoy learning with PPPs very much, $37.50 \%$ answer somehow and only $12.50 \%$ select not very. Such outcomes reveal the fact that students do enjoy learning via PPPs since it is a new way to get information and out of ordinary.

The last question was asked to know if our secondary schools are equipped with the technological means needed by teachers to support their lessons. According to teachers' answers (77.8\%) confirm the availability of these tools in the schools. On the other hand, $(22.2 \%)$ state that such tools are not available. 
Table 10. Avalability of Technology

\begin{tabular}{|l|l|c|c|}
\hline \multicolumn{2}{|c|}{} & Frequency & Percent \\
\hline \multirow{2}{*}{$\begin{array}{l}\text { Availability of } \\
\text { technology }\end{array}$} & No & $\mathbf{2}$ & $\mathbf{2 2 . 2 \%}$ \\
\cline { 2 - 4 } & Yes & 7 & $\mathbf{7 7 . 8 \%}$ \\
\cline { 2 - 4 } & Total & $\mathbf{9}$ & $\mathbf{1 0 0 \%}$ \\
\hline
\end{tabular}

\subsubsection{Students' Questionnaire}

The sample of our study consists of thirty five first year scientific stream pupils at Oued Taga secondary school (Batna). They all share the same learning background that they acquire in the middle school. They vary in their abilities, level and results. Since pupils are the main variable of this study, it is crucial to know their point of views and awareness about learning via educational technologies as Power Point Presentations. Thus, the most suitable tool to gather their opinions is a questionnaire. The questionnaire is given to them in the English sessions with their teacher of English present there for explanation and clarifications. The questionnaires are collected after the sessions.

The following table illustrates the participants' opinions about learning English:

\begin{tabular}{|l|l|r|r|}
\hline \multicolumn{2}{|c|}{} & Frequency & Percent \\
\hline \multirow{2}{*}{$\begin{array}{l}\text { Attitudes towards } \\
\text { learning Egnlish }\end{array}$} & not at all positive & $\mathbf{3}$ & $\mathbf{8 . 6 \%}$ \\
\cline { 2 - 4 } & a little positive & $\mathbf{2}$ & $\mathbf{5 . 7 \%}$ \\
\cline { 2 - 4 } & Somehow positive & $\mathbf{1 6}$ & $\mathbf{4 5 . 7 \%}$ \\
\cline { 2 - 4 } & very positive & $\mathbf{1 4}$ & $\mathbf{4 0 \%}$ \\
\hline & Total & 35 & $\mathbf{1 0 0 \%}$ \\
\hline
\end{tabular}

Table 11. pupils' Attitudes towards Learning English.

Then, they are asked about their teachers of English help in the classroom, they are asked to choose among the three options suggested.

\begin{tabular}{|c|c|c|c|}
\hline & & Number & Percent \\
\hline \multirow{3}{*}{$\begin{array}{l}\text { Teacher's } \\
\text { character }\end{array}$} & very helpful & 24 & $68.6 \%$ \\
\hline & Helpful & 11 & $31.4 \%$ \\
\hline & Total & 35 & $100 \%$ \\
\hline
\end{tabular}

Table 12. Teachers' help of their pupils

The reason lying behind this question is to discover if students are familiar with this tool (Power Point Presentations), and whether they were taught using it before. Table 5.34 and bar graph 12 discuss the participants' answers. 31.4\% of pupils assert that their teachers use PPPs sometimes, on the other hand, another group that make up $31.4 \%$ says they never used it. The rest proportion $37.1 \%$ agreed on the rare use of this technique by their teachers. As a result, we can say that teachers use this tool 
sometimes when they see that it serves the meaning and helps transmitting ideas easily, while teachers who tend to use PPPs rarely or never may be because they do not have access to such tools or they do not have equipments to use them. This means they do like to integrate them in their lessons, they are interested on such means, but certain circumstances prevent them from employing them.

Table 13. The Use of PPPs

\begin{tabular}{|l|l|c|c|}
\hline \multicolumn{2}{|c|}{} & Number & Percent \\
\hline \multirow{2}{*}{ Teachers' Use of } & Sometimes & $\mathbf{1 1}$ & $\mathbf{3 1 . 4 \%}$ \\
\cline { 2 - 4 } & Rarely & 13 & $\mathbf{3 7 . 1 \%}$ \\
\cline { 2 - 4 } & Never & $\mathbf{1 1}$ & $\mathbf{3 1 . 4 \%}$ \\
\cline { 2 - 4 } & Total & $\mathbf{3 5}$ & $\mathbf{1 0 0 \%}$ \\
\hline
\end{tabular}

The table below indicates pupils' opinions about being taught via power point presentations. The results imply that $48.6 \%$ of pupils said yes, they advocate that it is enjoyable and interesting because they are aware of its usefulness and effectiveness to facilitate their learning. On the contrast, the others $51.4 \%$ have a neutral attitude, possibly because they have not experienced this technology or just the do not care the way they are taught.

Table 14. Pupils' opinion about learning with PPPs.

\begin{tabular}{|l|l|c|c|}
\hline \multicolumn{2}{|c|}{} & Frequency & Percent \\
\hline \multirow{2}{*}{$\begin{array}{l}\text { Students' Liking } \\
\text { PPPs use }\end{array}$} & Yes & 17 & $\mathbf{4 8 . 6 \%}$ \\
\cline { 2 - 4 } & & 18 & $51.4 \%$ \\
\hline \multicolumn{2}{|c|}{ Neutral } & & \\
\hline
\end{tabular}

The last question in the pupils' questionnaire is a comparison between the traditional way of teaching (textbooks and white boards) and the innovative way that uses educational technologies (PPPs). The table and figure below demonstrate the answers obtained from students. The findings show that $22.9 \%$ say that both methods are the same for them, $68.6 \%$ confirm that indeed there is a difference between the two methods, while only $8.6 \%$ say that there is no difference between them. Therefore, the majority of the pupils share the same idea that there is a big difference between learning under the traditional method and using PPPs since they prefer the second one. They justify their answers saying that the latter is more enjoyable and attracting and vivid tool. It makes them (as they claim) active and motivated. 
Table 15. The difference between the old and new methods of learning

\begin{tabular}{|l|l|c|c|}
\hline \multicolumn{2}{|c|}{} & Frequency & Percent \\
\hline \multirow{2}{*}{$\begin{array}{c}\text { Difference between } \\
\text { Teaching Methods? }\end{array}$} & No & 3 & $\mathbf{8 . 6 \%}$ \\
\cline { 2 - 4 } & Yes & 24 & $\mathbf{6 8 . 6 \%}$ \\
\cline { 2 - 4 } & The same & $\mathbf{8}$ & $\mathbf{2 2 . 9 \%}$ \\
\cline { 2 - 4 } & Total & 35 & $\mathbf{1 0 0 \%}$ \\
\hline
\end{tabular}

\section{Conclusion}

The focus of our study is the use of Power Point Presentation in teaching English as a foreign language in Algerian secondary schools. The null hypothesis set at the very beginning of the research is that 'there is no significant difference between the pupils' scores and motivation through learning English by the traditional method or the innovative one. The study results show that technology plays a big role in language classes; it can be used as a tool to facilitate teaching and learning. As one of the most important goals of using new ways of teaching language in secondary schools is to promote pupils' motivation towards learning, Power Point Presentations is proved to have positive effects on pupils' scores. So according to the obtained results the posttest has shown an improvement in pupils' scores and achievements during the school year, and the continuous evaluation of learners approved that. The required value of $t$ at 0.02 level of significance, and for 29 degrees of freedom is $\mathrm{t}=2.462$, and as the obtained $\mathrm{t}$ (in the pre and post test) is 14.93, the level of means in the pre-test, the pupils got 8.07, and in the post-test they got 12.63. Thus, the difference is indeed significant.

We can say the results are globally significant, in other words, the results of our study validate our hypothesis. Hence, our research hypothesis is confirmed that there is a difference between teaching English for first year secondary school pupils using Power Point Presentations and teaching with the textbook and whiteboards. Another thing worth mentioning here is that the sample is taken from Oued Taga secondary school and the results of this study can be generalized only for this school.

Based on the findings of the present study and according to Radanov (2011), using Power Point software has several benefits for pupils. Its objective is acquisition of language in an interactive way. It offers multimedia possibilities like sounds, images, colour, action, design, i.e., different learning styles: visual, auditory, kinaesthetic, creative, which, at the same time, means that it is attractive to various learning types. The results of the study, further, reveal that those who have learned through Power Point software have better values in terms of the mean in the post-test in comparison with those of the pre-test. As a concluding remark, we can say that Power Point Presentations help teachers to draw students' attention during the lesson, which increases the effectiveness of the learning process. 


\section{Pedagogical Implications and Recommendations}

Educational technology is playing an important role in the teaching profession but it does not mean that teachers should be totally dependent on the ICT tools. They can use Microsoft Power Point as a tool, not as a method. They can incorporate the use of technology to teach as a way to add variety into classroom procedures so pupils do not get bored. It could be a form of motivation for the pupils and for the teachers themselves. This study can be replicated with more participants to understand the Power Point Presentations usage from a broader perspective. It is recommended for future researchers to investigate how to train secondary school teachers to use and implement Power Point Presentations in their courses.

Effective teachers strive to create a motivating classroom environment. According to Wiley et al. (2003), there are two types of environments: the physical and the psychological one; teachers need to consider both to promote engagement and learning. The Physical Environment involves building a comfortable and inviting place for learning, with many educational materials readily accessible for pupils. For example, in dealing with pronunciation, charts and diagrams, videos, tape recorders and the use of laboratories can support the teaching/ learning process. Additionally, variation of activities may, in all probabilities, enhance learners' improvement and prepare them to be self-regulated in the future. For instance, introducing new topics in classroom discussion, changing the shape of the classroom (U-shape), and encourage pupils be creative. As far as the Psychological Environment is concerned, it is based on the assumption that teachers need to promote community in their classroom, i.e., the teacher establishes frequent connections to pupils, motivating, supporting and encouraging them (creating a bridge between them).

Finally, the traditional method of teaching can still be the preferred instructional method by pupils, but teachers should pay more attention to the amelioration of this method rather than adapting a new technique by making it more interesting and live. Intelligent use of Power Point Presentations in teaching and learning is very important in increasing pupils' achievements.

\section{References}

Antherson, J. S. (2003). Learning and teaching: Intelligent.

Retrieved from http://www.dmu. Ac. UK/ Jamiea/learningintelligence.htm.

Cashman, T. J., \& Shelly, G. B. (2000). Microsoft Office 2000: Brief concepts and techniques (pp. 15-17). America: An International Thomson Publishing Company.

Cohen, Andrew D (1998). Strategies in learning and Using a Second language. Pearson 
Education Limited

Eggen, P. D. \& Kauchak, D. P. (2004). Educational Psychology: Windows on Classrooms.

Merrill Prentice Hall, Pearson Education International.

Fisher, D. L. (2003). Motivation as a contributing factor in second language acquisition. The Internet TESL Journal, IX(4). Retrieved 20 May 2006 from

\section{http://iteslj.org/Techniques/Fisher-PowerPoint.html}

Gier, V. S., \& Kreiner, D. S. (2009). Incorporating active learning with PowerPointbased lectures using content based questions. Teaching Psychology, 36(2), 134-139.

Jensen, L. (2001). Designing Lesson Plans In. M .Celce-Murcia (Ed.) Teaching

English as a Second or Foreign Language . USA: Heinle\&Heinle publishers 403

Harmer, J. (2001). The practice of English language teaching. London: Longman.

Miller, M. (2009). What the Science of Cognition Tells Us About Instructional

Technology. Change, 41(2), 16-17. Retrieved November 28, 2009, from Research Library.

Linnebrink, E.A., and Pintrich, P.R. (2003). The role of self-efficacy beliefs in student engagement and learning in the classroom. Reading \& Writing Quarterly, 19.

Radanov, L. (2011). PowerPoint presentations in EFL classroom- "PowerPoints" or a challenge? Retrieved June 2012, from http://www.britishcouncil.org/serbia-eltanewsletter-2011march powerpoint_presentations_in_efl_classroom.doc

Rank, T. Willum, T. \& Warren, C. (2011).Teaching English Using ICT: A Practical Guide For Secondary School Teachers. Continuum International Publishing Group

Selinger \& Shohamy (1989). Second Language Research Methods. Oxford: Oxford University Press. (Tuckman, 1969 quoted in Argyle, 1969).

Tufte, E. (2003, Nov. 9). PowerPoint is evil. Wired. Retrieved Dec. 20, 2004 from

\section{http://www.wired.com/wired/archive/11.09/ppt2.html}

Wiley, J. \& Sons, Inc (2003). Handbook of Psychology: Volume 7: Educational Psychology. Hoboken, New Jersey.

Wolfe, P. (2001). Brain matters: Translating research into classroom practice. Alexandria, VA: Association for Supervision and Curriculum Development. Retrieved November 28, 2009, from 
http://www.ascd.org/publications/books/101004/chapters/LongTerm_Me mory@_The_Brain's_Storage_System.aspx

Appendix

Classroom Observation Checklist

Name :

Date :

School :

Time :

\begin{tabular}{|c|c|}
\hline Criteria / Area Observed & Description/ Comments \\
\hline $\begin{array}{l}\text { - Setting : } \\
\text { Number of students, language used in } \\
\text { the class, Setting map }\end{array}$ & \\
\hline $\begin{array}{l}\text { Materials: } \\
\text { White Board, Textbook( } \\
\text { dominates?), handouts, pictures... }\end{array}$ & \\
\hline $\begin{array}{l}\text { Teaching Aids( Manipulatives) } \\
\text { Overhead Projecter, maps, audio } \\
\text { visual aids, ( are they visible, } \\
\text { audible...) }\end{array}$ & \\
\hline $\begin{array}{l}\text { - Teachers' Role: } \\
\text { Source of information, guider, } \\
\text { facilitator, helpful, serious, active, } \\
\text { motivating, encouraging... }\end{array}$ & \\
\hline $\begin{array}{l}\text { Students' Reaction: } \\
\text { Listening, participating, } \\
\text { concentrating, feeling confused, } \\
\text { motivated, understanding the lesson } \\
\text { content, working individually or in } \\
\text { groups }\end{array}$ & \\
\hline
\end{tabular}

Your conclusions

Overall, how did you feel the session went?

Was the pace of the session about right / too slow / too fast?

How would you judge the level and complexity of the material, in relation to the students' capacities?

What were the outcomes of the session? Were they in line with the objectives?

Was there anything that you would have added to the lesson / left out / done differently?

What would you say were the principal strong points and weak points of the materials used in this session, for the students?

- $\quad$ Strong points

- Weak points

And what would you say were the principal strong points and weak points of the materials, for the teacher?

- $\quad$ Strong points

- Weak points

Do you have any suggestions for improving the activity you observed or the way it is presente 